\title{
Shape Exploration Analysis on Sungkai Wood Fossil
}

\author{
Susmitha Fauziah $^{1}$, Yoga Pujiraharjo ${ }^{2}$ \\ ${ }^{1}$ Desain Produk, Fakultas Industri Kreatif, Bandung, Indonesia \\ ${ }^{2}$ Desain Produk, Fakultas Industri Kreatif, Bandung, Indonesia \\ Susmithaf55@gmail.com (Susmitha Fauziah), yogapujiraharjo@gmail.com (Yoga Pujiraharjo)
}

\begin{abstract}
Sungkai wood fossil is one of the fossils found in Merangin district, Jambi. The availability of abundant sungkai wood fossil makes it an industry that specializes in sungkai wood fossil. In the industry processed sungkai wood fossil and made it into a furniture, made of large chunks with every outer shell and some parts are thrown away and not utilized. The remains of this untapped piece or waste becomes a great potential for reprocessing into a useful product. In its completion, the experimental method is done by implementing the exploration on the sungkai wood fossil, The exploration method that is used is the exploration of the shape, Where the exploration parameters of the shape used are expression, size and visual. Based on the results of the exploration of the shape with these parameters produced a shape that can utilize the remaining pieces of sungkai wood fossil maximally. Aiming to find the remaining potential pieces of sungkai wood fossils can be utilized with simple processing.
\end{abstract}

Keywords: Sungkai wood fossil, Exploration, Waste.

\section{INTRODUCTION}

In one of the provinces in Indonesia namely Jambi is an area that has a source of discovery of sungkai wood fossil, in the Merangin Regency area. According to Andianto et al. (in Listya Mustika Dewi, 2013), wood fossil is wood that's been petrified where all organic materials have been replaced by minerals, with wooden structure still awake.

The availability of abundant sungkai wood fossils make the area there are discussing industrial processing of sungkai wood fossil. Utilization of sungai wood fossil processing in Merangin Regency is by making it a furniture objects such as tables and chairs that was formed with the simple with the use of material of the sungkai wood fossil.

Based on the background of the issue regarding the remaining pieces of the sungkai wood fossil then done processing with the process of experimentation, which would later get new results for exploited into the material more useful. Research using experimental physically to get a visual form that aims to search the oportunities the remaining pieces of the sungkai wood fossil can be used with simple processing. Utilization of waste sungkai wood fossil as a means aimed at facilitating for the community in merangin regency.

The methods used in this research is a method of experimentation. The use of the method wants because in the process of doing by doing some exploratory trial against materially used. This data is used in analysis to analyze the results of the collection of data obtained, as a result of wants produced some results that are further analyzed to obtain a visual exploration of forms to suit the needs of the design.

\section{THEORETICAL BACKGROUND}

Based on the phenomenon is examined, the definition of sungkai wood fossil expressed Andianto et al. (in Listya Mustika Dewi, 2013:1) suggests that the wood fossil is wood that's been petrified where all organic materials have been replaced by minerals (silica and a kind of quartz), with wooden structures stay awake. The process of the formation of fossil wood starts from the influx of water containing 
minerals into the cells of the tree lines the lignin and cellulose which decomposing so that it becomes rock.

Wood fossil is formed through a very long process, in the process of its formation changes chemically and physics, this is supported by the opinion of Listya Mustika Dewi (2013:1) "The process of the formation of wood fossil similar to the formation of fossils of other materials, namely because permineralisasi is chemically and physics through a very long process. Based on the exposure by Listya Mustika Dewi (2013:2) "wood Fossils have been found in Indonesia, namely West Java, Central Java, Kalimantan, Jambi and Flores".

According to Mandang and Kagemori (Listya Mustika Dewi 2013:2) suggested that since more than three decades ago, wood fossils have been excavate only used as a commodity traded both in the country or abroad. Based on the availability of the raw material wood fossil is a fairly overflow but only lacking skills in of processing so that's still a lot of abuse in its utilization.

\section{RESEARCH METHOD}

\subsection{Exploration}

According to Bram Palgunadi (2007:270), exploration can be defined as activities conducted in the framework of the browsing or search a thing (problem, ideas, opportunities, or other systems), in order to gain or expand understanding, understanding, deepening or experience. It was concluded that exploration is gathering information through literature reviewand field study to get results that match that is being examined.

Exploration is going to do is cultivate the material the rest of the sungkai wood fossil cut into a material that can be used again it will serve as a useful product. Through the process of assessment of the literature data was sought regarding sungkai wood fossil waste and also through the collection of data with field review how the results obtained in the shape of information about the related data.

\subsection{Design Principles}

According to Bambang Irawan \& Pricillia Tamara (2013:32) that is, a work of art that is beautiful, whatever its shape must have been through a process of creation and setup that has been well thought out in such a way. On the process of structuring a way there are principles that must be understood, so that the perpetrators of art capable of translating his work into a work of art. The principle of the arrangement is a blend of legal or planning to determine how to combine elements of a way to achieve certain desired effects and aesthetic value.

\subsection{Shape}

According to Bambang Irawan \& Pricilla Tamara (2013:78) that is, essentially a shape of inspiration can be taken from nature or from various basic shapes created by humans. Therefore, the form itself can be categorized into two types, namely:

1. Natural Shape

All shape in the universe, the shape that is more free and not bound by the rules of the shape created by humans.

\section{Artificial Shape}

The shape created by humans through processing. Its realization has always had a basic shape which is also the result of human engineering. The artificial shape is divided into two, namely the basic shape a two dimensional and three dimensional base.

According to Bambang Irawan \& Pricilla Tamara (2013:78) each form has the size, the look, the visual. There are two things that are not always there on the shapes, colours and textures. However, both of these are capable of providing their own specialtouches on the final result of the forms, which can increase its aesthetic value.

\subsection{Preview Field}

Based on the review of the field by conducting observation against the intended source, about the availability of sungkai wood fossil existing surroundings Merangin Regency society, it brings that there is a lot of scrap wood fossil from the creation of an industry, the rest are not reused but stacked so that it becomes an actual waste can still be processed back into a high-value product with a touch of design.

Sungkai wood fossils are usually used as furniture making materials such as tables, chairs and cabinets. sungkai wood fossils are used because its availability is fairly abundant, sungkai wood fossil has several kinds of, among others:

\section{Mountain Sungkai Wood Fossil}

This type of fossil is named based on the place where the fossil finds, it is more lenient than others. Motive owned exactly like the pattern of the wood by showing clear wood fiber. 


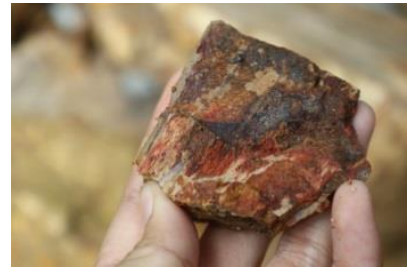

Figure 1. Mountai Sungkai wood fossil

\section{River Sungkai Wood Fossil}

Fossils of this type has a pattern of not too many most of the resulting color is black and dark brown. Characteristics owned pretty hard because results in the formation of water by absorbing a considerable amount of minerals and other content which is contained in the water of this fossil place awash in quite a long time.

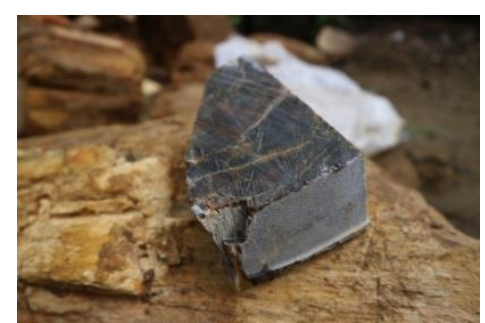

Figure 2. River Sungkai Wood Fossil

\section{Swamp Sungkai Wood Fossil}

Fossil of this type have a unique pattern than the other because of the irregular shaped community about calling it a stylised batik. Batik pattern obtained is the natural results are naturally the result of quite a long buried by up to hundreds of millions of years ago. Characteristics of fossil types owned swamp is pretty hard because the content of the absorbed during buried or inundated by water marshes. This type of fossil is pretty much favored by local people as a media house decoration or as a decorating motive because the pond is quite unique.

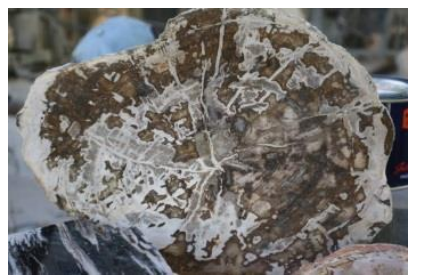

Figure 3. Swamp Sungkai Wood Fossil

The results of exploration fossil pieces of waste wood against sungkai processed by using the physical exploration of the material being used against, that would result from such exploration processed back into a shape to be used as the primary material in the making of the design of the product.

\section{RESULT AND DISCUSSION}

\subsection{Analysis Of The Shape}

Sungkai wood fossil waste which will be processed into a refined have limits of processing in the form of the exploration process into consideration. This analysis is carried out to find out what influences the shape. Each shape has the size, the look, and visual.

Table 1. Analysis Of The Form On The Size

\begin{tabular}{|c|c|c|c|}
\hline No. & Type & Size & Result \\
\hline 1 & $\begin{array}{l}\text { Mountain } \\
\text { Sungkai } \\
\text { wood fossil } \\
\end{array}$ & \multirow{3}{*}{$\begin{array}{l}\text { Cut with a } \\
\text { thickness of } 1 \\
\mathrm{~cm} \text { of each } \\
\text { type } \\
\text { sungkai wood } \\
\text { fossil }\end{array}$} & $\begin{array}{l}\text { Cracked, due to the charac- } \\
\text { teristics of the mountain } \\
\text { sungkai fossil are fragile }\end{array}$ \\
\hline 2 & $\begin{array}{l}\text { Swamp } \\
\text { Sungkai } \\
\text { wood fossil }\end{array}$ & & $\begin{array}{l}\text { Doesn't cracked, because } \\
\text { swamp sungkai wood fossil } \\
\text { has a strong and solid char- } \\
\text { acteristic }\end{array}$ \\
\hline 3 & $\begin{array}{l}\text { River } \\
\text { sungkai } \\
\text { wood fossil }\end{array}$ & & $\begin{array}{l}\text { Doesn't cracked, because } \\
\text { the river sungkai wood } \\
\text { fossil has a strong and solid } \\
\text { characteristc }\end{array}$ \\
\hline
\end{tabular}

Table 2. Analysis Of The Form On The Pattern

\begin{tabular}{|l|l|l|l|}
\hline No. & Type & Size & Result \\
\hline 1 & $\begin{array}{l}\text { Mountain } \\
\text { sungkai } \\
\text { wood } \\
\text { fossil }\end{array}$ & & $\begin{array}{l}\text { It showed wood pattern like } \\
\text { the origin of the wood, the } \\
\text { mountainsungai wood } \\
\text { fossil is not changing too } \\
\text { much due to being buried in } \\
\text { soil that is dry. }\end{array}$ \\
2 & $\begin{array}{l}\text { Swamp } \\
\text { sungkai } \\
\text { wood } \\
\text { fossil }\end{array}$ & $\begin{array}{l}\text { The pattern the cut to } \\
\text { after tharac- } \\
\text { tee thistic of each } \\
\text { sungkai fossil }\end{array}$ & $\begin{array}{l}\text { Has irregular pattern with a } \\
\text { mix of many colors. }\end{array}$ \\
& $\begin{array}{l}\text { River } \\
\text { sungkai } \\
\text { wood } \\
\text { fossil }\end{array}$ & $\begin{array}{l}\text { Has the pattern of elongated } \\
\text { with a dominant color is } \\
\text { dark, because the process of } \\
\text { decay in the water }\end{array}$ \\
\hline
\end{tabular}

Tabel 3. Analysis On Visual Shape

\begin{tabular}{|l|l|l|l|}
\hline No. & Type & Size & Result \\
\hline 1 & $\begin{array}{l}\text { Mountain } \\
\text { sungkai } \\
\text { wood fossil }\end{array}$ & & $\begin{array}{l}\text { The result shows that the fossil } \\
\text { looked like a wood, with brown } \\
\text { colour and wood patterns are } \\
\text { clearly visible. }\end{array}$ \\
2 & $\begin{array}{l}\text { Swamp } \\
\text { sungkai } \\
\text { wood fossil }\end{array}$ & $\begin{array}{l}\text { Hi gloss } \\
\text { Coated } \\
\text { batik motive with various color } \\
\text { and pattern shape }\end{array}$ \\
\hline 3 & $\begin{array}{l}\text { River } \\
\text { sungkai } \\
\text { wood fossil }\end{array}$ & $\begin{array}{l}\text { The results obtained are sol- } \\
\text { id and strong look be- } \\
\text { cause black is dominant. }\end{array}$ \\
\hline
\end{tabular}




\subsection{Analysis Of Materials}

sungkai wood fossil waste is a material used in the process of exploration, with shape of waste in the shape of slabs that are the result of cutting of sungkai wood fossil. The cutting is done using grinding machine to get results in the shape of slabs, the process is done by using the eyes of different grinding to an end result that is getting the most out of the slab that has a flat surface.

Table 4. Table of Materials Analysis

\begin{tabular}{|c|c|c|}
\hline Type & Advantages & Disadvantages \\
\hline $\begin{array}{l}\text { Mountain } \\
\text { Sungkai wood } \\
\text { Fossil }\end{array}$ & $\begin{array}{l}\text { The pattern of the wood } \\
\text { which is owned is still } \\
\text { very clearly visible } \\
\text { The bark on the outside } \\
\text { really still like the origi- } \\
\text { nal wood's just been } \\
\text { petrified }\end{array}$ & $\begin{array}{l}\text { Types of this one is } \\
\text { very easy to crack } \\
\text { because of its outer } \\
\text { surface is fragile. } \\
\text { Large fossil pores } \\
\text { enough and slighly } \\
\text { fragile, it was not too } \\
\text { shiny when smoothed. }\end{array}$ \\
\hline $\begin{array}{l}\text { River sungkai } \\
\text { wood fossil }\end{array}$ & $\begin{array}{l}\text { Harder than the type } \\
\text { of mountain sungkai } \\
\text { wood fossil. } \\
\text { Go very shiny when get } \\
\text { smoothed. }\end{array}$ & $\begin{array}{l}\text { The color that } \\
\text { available on this } \\
\text { material is only black, } \\
\text { white and brown. } \\
\text { It is difficult to cut } \\
\text { because it is hard } \\
\text { characteristic. }\end{array}$ \\
\hline $\begin{array}{l}\text { Swamp sungkai } \\
\text { wood fossil }\end{array}$ & $\begin{array}{l}\text { It has a unique pattern } \\
\text { that is resembling batik } \\
\text { pattern. } \\
\text { A variety of shades and } \\
\text { colors in one section of } \\
\text { the sungkai wood fossil. } \\
\text { There is a transparent } \\
\text { part founded on several } \\
\text { piece of this type wood } \\
\text { fossil. }\end{array}$ & $\begin{array}{l}\text { Difficult to cut } \\
\text { because of the type of } \\
\text { wood is the hardest } \\
\text { between two other } \\
\text { types. }\end{array}$ \\
\hline
\end{tabular}

Tabel 5. Analysis Activity

\begin{tabular}{|c|c|}
\hline Activities & Analysis \\
\hline 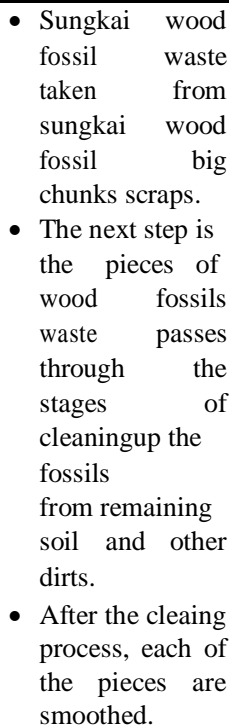 & $\begin{array}{l}\text { - The rest of the pieces of wood used to serve } \\
\text { as the new shape. } \\
\text { - Wood fossil mashed will produce fibers } \\
\text { and textures on the surface of sungkai wood } \\
\text { fossil. } \\
\text { - The process of smoothing using grinding } \\
\text { with grinding eye of various types are } \\
\text { used,starting from using sandpaper until } \\
\text { using polisher to polish the surface for Shin- } \\
\text { er sungkai wood fossil result. }\end{array}$ \\
\hline
\end{tabular}

Based on the results of the analysis of the initial exploration by conducting an analysis of the shape and materials

obtained as a result of that waste treatment sungkai wood fossil obtained form the slab with a thickness of at least $1 \mathrm{~cm}$ with a width varying availability of sungkai wood fossil waste.

\subsection{The Analysis of the Process of Exploration Utilization} Shape.

Tabel 6. Analysis Of Exploration Proces

\begin{tabular}{|c|c|c|c|c|}
\hline No & Activities & Methods & Result & Description \\
\hline 1 & $\begin{array}{l}\text { Artificial } \\
\text { shape }\end{array}$ & $\begin{array}{l}\text { Cut using } \\
\text { grinding to } \\
\text { get the ap- } \\
\text { propriate } \\
\text { shapes }\end{array}$ & $\begin{array}{l}\text { From slab } \\
\text { formed produci } \\
\text { ng a triangular } \\
\text { shape, square, } \\
\text { rectangles and } \\
\text { pentagons }\end{array}$ & $\begin{array}{l}\text { The ad- } \\
\text { vantages } \\
\text { gained } \\
\text { fromthis } \\
\text { method is } \\
\text { the shapes } \\
\text { produced are } \\
\text { neater. } \\
\text { The } \\
\text { disadvantage } \\
\text { s is it takes a } \\
\text { long time } \\
\text { and also the } \\
\text { accuracy at } \\
\text { the time } \\
\text { when cutting } \\
\text { the fossil. }\end{array}$ \\
\hline 2 & $\begin{array}{l}\text { Natural } \\
\text { Shape }\end{array}$ & $\begin{array}{l}\text { Hit with } \\
\text { a hammer an } \\
\mathrm{d} \text { chisel in } \\
\text { order to get } \\
\text { the results of } \\
\text { a natural } \\
\text { fault line }\end{array}$ & $\begin{array}{l}\text { The result } \\
\text { obtained is a } \\
\text { natural fault } \\
\text { line forms with } \\
\text { different sizes } \\
\text { based on the } \\
\text { results of fibers } \\
\text { that are owned } \\
\text { by sungkai } \\
\text { wood fossil, } \\
\text { and the end } \\
\text { result produces } \\
\text { a square and } \\
\text { rectangular } \\
\text { shapes. }\end{array}$ & $\begin{array}{l}\text { The advan- } \\
\text { teges gained } \\
\text { is it do not } \\
\text { need a long } \\
\text { time to get } \\
\text { the results. } \\
\text { The disad- } \\
\text { vantages of } \\
\text { this experi- } \\
\text { ment is a } \\
\text { different size } \\
\text { from each } \\
\text { piece. }\end{array}$ \\
\hline
\end{tabular}

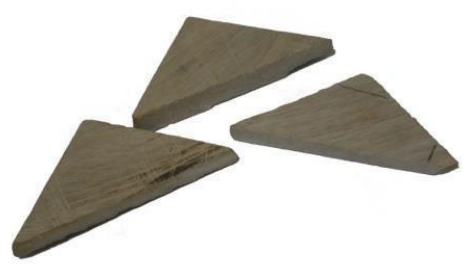

Figure 4. Piece Of Triangular Shape 


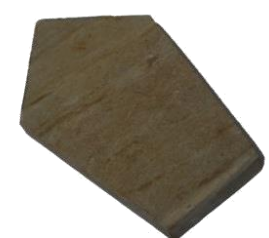

Figure 5. Piece Of Pentagon Shape

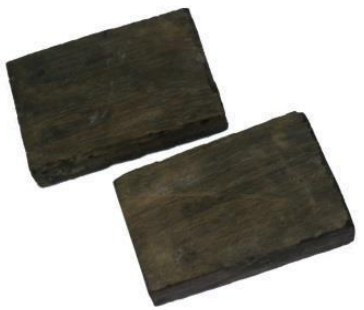

Figure 6. Piece Of Square Shape

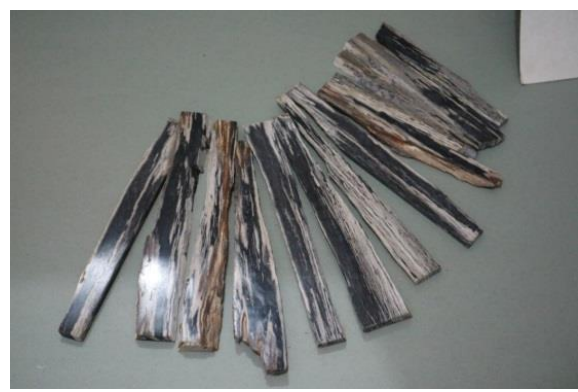

Figure 7. Piece Of Natural Shape

Based on the results of exploration with the utilization of the material obtained that:

1. Form of artificial (geometry) produces 4 pieces shape triangle, square, rectangle and pentagons.

2. Natural shape produces two shapes which is square and rectangle.

3. The shape results taken is rectangular shape and square shape, because these shapess shows more pattern of the sungkai wood fossil from its dominant length

\subsection{The process of utilization of Materials}

In this form of utilization of process stages are stages where do exploration towards form which had previously been obtained i.e. Rectangle. Rectangular pieces of this coupled with a few ingredients to produce new compositions.

Tabel 7. Utilization Process of Shape

\begin{tabular}{|c|c|l|l|l|}
\hline No & $\begin{array}{c}\text { Activiti } \\
\text { es }\end{array}$ & \multicolumn{1}{|c|}{ Method } & \multicolumn{1}{|c|}{ result } & $\begin{array}{l}\text { Descriptio } \\
\text { n }\end{array}$ \\
\hline 1 & $\begin{array}{l}\text { Mixed } \\
\text { with the } \\
\text { resin }\end{array}$ & $\begin{array}{l}\text {-Paste each fossil } \\
\text { piece with clear } \\
\text { ductape on the front } \\
\text { and back side, give } \\
\text { a bit of space } \\
\text { between the fossils, }\end{array}$ & $\begin{array}{l}\text { The results } \\
\text { obtained } \\
\text { are the the } \\
\text { rhythm } \\
\text { arrangemen } \\
\mathrm{t} \text { in shape }\end{array}$ & $\begin{array}{l}\text { The } \\
\text { advantages } \\
\text { gained are } \\
\text { making sto } \\
\text { ne becomes } \\
\text { solid becau }\end{array}$ \\
\hline
\end{tabular}

Table 7, cont.

\begin{tabular}{|c|c|c|c|c|}
\hline & & $\begin{array}{l}\text { then pour rasin } \\
\text { liquid into the space } \\
\text { between the fossils. } \\
\text {-Putting the pieces } \\
\text { of the sungkai wood } \\
\text { fossil in a rectangle } \\
\text { Container and } \\
\text { arrange the wood } \\
\text { fossils side by side } \\
\text { with a litlle bit of } \\
\text { space between the } \\
\text { fossils. And pour } \\
\text { liquid resin into the } \\
\text { spaces around the } \\
\text { wood fossils but } \\
\text { leaves the top of the } \\
\text { fossils exposed. }\end{array}$ & $\begin{array}{l}\text { which } \\
\text { consisted of } \\
\text { resin and } \\
\text { piece of } \\
\text { sungkai } \\
\text { wood } \\
\text { fossil. }\end{array}$ & $\begin{array}{l}\text { se } \\
\text { each pores } \\
\text { cavity are fi } \\
\text { lled by liqui } \\
\text { d resin and } \\
\text { strong. } \\
\text { The } \\
\text { disadvantag } \\
\text { es is the } \\
\text { liquid resin } \\
\text { took quite a } \\
\text { long } \\
\text { time on the } \\
\text { drying } \\
\text { process }\end{array}$ \\
\hline 2 & $\begin{array}{l}\text { Glued w } \\
\text { ith use } \\
\text { power } \\
\text { glue }\end{array}$ & $\begin{array}{l}\text { Uniting each fos- } \\
\text { sil pieces } \\
\text { with different } \\
\text { types. }\end{array}$ & $\begin{array}{l}\text { The results } \\
\text { obtained } \\
\text { are gener- } \\
\text { ating } \\
\text { new pattern }\end{array}$ & $\begin{array}{l}\text { The } \\
\text { advantages } \\
\text { of the } \\
\text { process is it } \\
\text { can be done } \\
\text { in a short } \\
\text { time. } \\
\text { The } \\
\text { disadvantag } \\
\text { es } \\
\text { is each piec } \\
\text { e easily det } \\
\text { ached due } \\
\text { the } \\
\text { power glue } \\
\text { got quickly } \\
\text { dried and } \\
\text { causing the } \\
\text { glue could } \\
\text { not get into } \\
\text { the fossil } \\
\text { pores } \\
\text { optimally. }\end{array}$ \\
\hline 3 & $\begin{array}{l}\text { Bond- } \\
\text { ed/glue } \\
\text { with gla } \\
\text { ss glue }\end{array}$ & $\begin{array}{l}\text { Uniting each piece } \\
\text { with glass glue }\end{array}$ & $\begin{array}{l}\text { The results } \\
\text { obtained } \\
\text { are each pie } \\
\text { ce of stone } \\
\text { are bonded. }\end{array}$ & $\begin{array}{l}\text { The } \\
\text { advantages } \\
\text { is fossil } \\
\text { pieces are q } \\
\text { uickly } \\
\text { merges } \\
\text { with quite } \\
\text { short } \\
\text { The } \\
\text { disadvantag } \\
\text { es is the } \\
\text { result of a } \\
\text { glass glue } \\
\text { has dried is } \\
\text { like rubber } \\
\text { when there } \\
\text { is } \\
\text { one interest } \\
\text { ed then enti } \\
\text { rely would } \\
\text { be inter- } \\
\text { ested and } \\
\text { able to be } \\
\text { apart of it } \\
\text { all. }\end{array}$ \\
\hline
\end{tabular}


Based on the results of the exploration process form obtained that:

1. The process of blending with resins constitute the right way in the utilization of each piece of sungkai wood fossil.

2. Using the resin produces a new rhythm.

\subsection{Analysis exploration of Visual Shape}

This shape of visual exploration process aims to get the visual exploration of the process of utilization shape where in the process of exploration has been conducted an experiment between the sungkai wood fossil material with chemicals to get results that are most appropriate for use in the next step. The results obtained are large sized slab which further cut to get the final form.

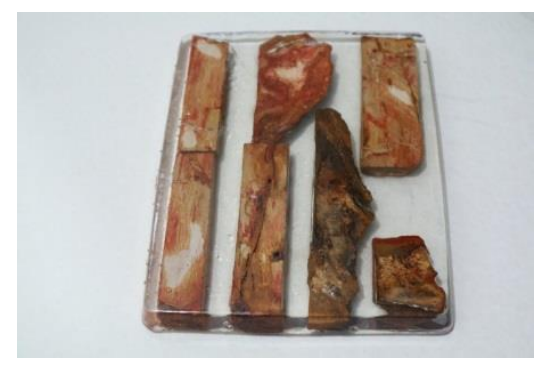

Figure 8. fossil pieces and resin mold

Table 8. Exploration Of Visual Shape

\begin{tabular}{|l|l|l|}
\hline No & Shape & $\begin{array}{l}\text { Analysis } \\
\text { The first experiment: } \\
\text { The advantages of this shape of } \\
\text { pentagon is one shape that has } \\
\text { many sides. }\end{array}$ \\
\hline 2. & $\begin{array}{l}\text { The disadvantages is the cutting } \\
\text { process to make thi shape } \\
\text { is difficult. }\end{array}$ \\
\hline & $\begin{array}{l}\text { Second experiment: } \\
\text { The advantages of triangular } \\
\text { shape is that it can be used as a } \\
\text { shape of that could generate other } \\
\text { shapes with combining several } \\
\text { pieces triangular shape and } \\
\text { rhythm. }\end{array}$ \\
\hline
\end{tabular}

Table 8, cont.

\begin{tabular}{|l|l|l|}
\hline 3. & $\begin{array}{l}\text { The third experiment: } \\
\text { The advantages of the square } \\
\text { shape is easy to set up. }\end{array}$ \\
\hline
\end{tabular}

Based on the results of exploration with the experimental method is obtained that:

1. Triangular shape represents the best results from the visual form of exploration fossil wood sungkai.

2. The triangle is composed of many different types of deductions so that in the form can be chosen according the existing material.

\section{CONCLUSION}

Based on the results of the exploration of form made using waste materials of fossil wood sungkai, then obtained a conclusion as follows:

1. The process of the formation of sungkai wood fossil waste slabs make it easy being for processed into new shapes.

2. The best shape of triangular shape because it has so many different types of triangle can combine several types of compositions in one form.

3. Exploration of sungkai wood fossil and resin is one way that is easy to do so that it can be used as an example for the industry of sungkai wood fossil craftsmen for utilizing waste amply cut became more useful because it is based on the industry have been using resin. Because some industries using res-ins as additional material it's just less to maximize its use.

\section{REFERENCES}

[1] Irawan, Bambang dan Tamara, Priscilla. 2013. Dasardasar Desain.. Jakarta: Griya Kreasi.

[2] Palgunadi, Bram, 2007. Desain Produk 1: Desain, desainer, dan proyek desain. Bandung: Penerbit ITB.

[3] Palgunadi, Bram, 2008. Desain produk 2: Analisis Konsep Desain. Bandung: Peberbit ITB

[4] Dewi, LM, 2013. Penelitian Fosil Kayu: Status dan Prospeknya di Indonesia, Disajikan Pada Diskusi Litbang Anatomi Kayu Indonesia di IPB Interational Convention Center, 3 Juni 2013. http://fordamof.org/files/Makalah_fosil_kayu_Listya _3_June_2013_latestVersion.pdf 